\title{
FOLK APPLIED ART AS AN INTEGRAL PART OF UZBEK NATIONAL AND MODERN ARCHITECTURE (ON THE EXAMPLE OF ANDIJAN ARCHITECTURE)
}

\section{Bobirjon Botirjonovich Kadyrov}

Teacher, Department "Fine Arts And Engineering Graphics" Faculty Of Art History, Andijan State University, Uzbekistan Isroiljon Kadirjonovich Urinbaev

Teacher, Department "Fine Arts And Engineering Graphics" Faculty Of Art History, Andijan State University, Uzbekistan

\section{ABSTRACT}

Experts comment on the formation of four schools of architecture - Samarkand, Bukhara, Tashkent, and Fergana (Kokand Khanate), their distinctive features. We do not have a source. During the study of the architectural monuments of that period and preserved to this day, we got acquainted with the activities of several masters, original architects, and masters of architectural decoration, dynasties of masters. LI Rempel writes it developed in mystery painting and tiling.

KEYWORDS: - Art history, architecture, urban planning, national culture, design, integration, element, project.

\section{INTRODUCTION}

The interior decoration of the building comprises the ceiling and wall parts of the room. Sometimes, we also encounter doors and columns from carvings. Before writing about architectural interior decorations, we need to have a general understanding of the architecture that is the basis for decorations. First, the artistic skills of the carpenter play an important role in construction, especially in roofing. Doctor of Arts P. "There are three ways to cover the roof, which are as a gable column and a lamp ceiling," Zohidov said. The ceiling of the building is the main surface, the area where the painting is applied. It, therefore, requires us to give some insight into the roof of the building and its parts.

"Ship (ceiling) means a room, the top of the interior of the house, the surface of the roof from the inside of the room."

1) In the Vassajuft method, to cover a simple roof, first, a beam is thrown into the wall, vassals are collected from the top between the two beams, and wicker, reeds, or twigs are then pressed from the top with mud and soil. The roofs of luxury buildings such as hotels and mosques are much more complex, with additional parts such as, then the roof is closed 
CURRENT RESEARCH JOURNAL OF PEDAGOGICS 2(12): 90-93, December

2021 DOI: https://doi.org/10.37547/pedagogics-crjp-02-12-18

ISSN 2767-3278

(C)2021 Master Journals

Crossref do: 81 Google

Accepted 18 ${ }^{\text {th }}$ December, 2021 \& Published $23^{\text {th }}$ December, 2021

and each part is decorated with individual patterns.

2). Ceiling columns are more complex, with additional columns raising the diseased part of the ceiling, resulting in deep pools in the ceiling. In some cases, the pool is covered in a domed style. Such ceiling parts are also decorated with unique and appropriate patterns.

3) Lamp style ceiling has two different views and is called a printed and hanging lamp. The hanging lamp is fastened from the inside of the room by hanging plywood or DVP on the beams on both sides with the capital, and a wide flat surface is formed throughout the room. Drawing patterns on such surfaces is a special pleasure for masters. The view of the ceiling, which is nailed to the top of a wooden beam with a flat finish with a grater on one side of the print lamp.

Each of the three types of ceiling pieces has its own patterns, which are given with mutually compatible paints, which have been skillfully used by painters. Covered in this style, the rooms of the building look very elegant, majestic, and airy, opening the heart and lifting the mood of the person Khojar Noyib (Ark) madrasah, in the Old City of Andijan, is the oldest architectural monument in the region, dating back to the 14th century. Detailed information about the monument, which was taken under state protection as an architectural object of cultural heritage, is given in the passport of art critic D. Yusupov and in the book about woodcarver Usta Tesha Ismailov. The repair work involves masters of wood and plaster carving, enamel painting and tiling of the national applied decorative arts. The entrance gate to the madrasa from the roof of Bazar Street, the doors of the rooms, 6 columns of the khanaqah and the entrance gate to the madrasah were made by Andijan master Teshaboy Ismoilov in the style of wood carving. The interior of the khanaqah, the porch, the gatehouse and some of the rooms are decorated by Kokand masters on the basis of the ancient traditions of the Fergana Valley school of mystical painting.

The uniquely styled courtyard view looks like an interior relative to the outside. The entrance to each room consists of a separate altar-shaped wall surface and low carved doors in the middle, which form a single composition with a dome, a prayer hall and a gatehouse. The ceiling is finished with 8-sided three-row muqarnas ornaments and covered in the style of assault. As a result of master Tesha's design and charm of each door with special care, the low doors have become examples of applied decorative art that gives a majestic, pleasant mood. The embroidered doors are decorated with patterns "Kushband islimiy", "choryaproq madohil", "mehrobi madohil", "madohil islimiy", "aygul islimiy", "chinnigul islimiy", "namoyan". The embroidered doors are decorated with patterns "Kushband islimiy", "choryaproq madohil", "mehrobi madohil", "madohil islimiy", "aygul islimiy", "chinnigul islimiy", "namoyan".

On the occasion of the 530th anniversary of the birth of Zakhiriddin Muhammad Babur, a museum dedicated to the king and poet, statesman and scholar Babur was built in the architectural monument of the madrasah "Khojar Noyib" ("Inside the Ark"). The museum has become one of the most popular places in the city, which is regularly visited not only by locals but also foreign tourists. The passport of the cultural heritage site compiled by Yusupov, the article, I. Azimov's book contains detailed information. The passport of the monument describes the monument as follows: "The madrasa is a unique example of national architectural art, built in the 1870 s by Namangan masters Kyrgyzboy and Mamajon. The uniqueness of the monument is, first of all, in its distant form - in its appearance, architectural solution, in the art of bricklaying, which can be recognized as an example of high craftsmanship, 
CURRENT RESEARCH JOURNAL OF PEDAGOGICS 2(12): 90-93, December

2021 DOI: https://doi.org/10.37547/pedagogics-crjp-02-12-18

ISSN 2767-3278

(C)2021 Master Journals

\section{Crossref do) 8 Google}

Accepted $18^{\text {th }}$ December, 2021 \& Published 23 th December, 2021

in the art of calligraphy and beautiful painting, ending with five tower-shaped bouquets. It is known that the most skilled masters of their time in the field of bricklaying, enamel painting, wood carving and calligraphy, as well as architecture, participated in the construction of the madrasah and artistic decoration.

During the renovation (the 1980s), the carved patterns of the entrance door to the mosque by the inner courtyard were recreated by the woodcarver Tesha Ismoilov, taking a pattern from the main gate. The ceiling of the inn is columnar, if a covered beam, partially covered by a lamp. The courtyard of the madrasa was rectangular, surrounded on three sides by cells covered in the assault method, and they served as classrooms. The qibla side of the monument is a majestic mosque. Since they built the madrasa of old-fashioned square bricks of high taste and skill, there was no need to plaster its interior and exterior walls. Among the unique examples of painting, we read the name of Master Sadullo and realize that the creator of dis beauty is the experts who recognize local Master Sadullo. dis as an invaluable example of the architecture of the Kokand Khanate period. The madrasah was the center of enlightenment of its time, taught by qualified teachers, and many students received education, religious and secular education. The madrasah is under the protection of the state under the name of "Otaqozi khoji" mosque as an object of the cultural heritage of republican significance.

The rapid development of urban planning in the years of independence, the international standard of creativity, and national identity pose great challenges to our architects. The religious, public and administrative buildings under construction are built primarily in harmony with the ancient national architectural traditions and modern spirit in terms of architectural appearance and artistic solution. Their exterior and interior decorations are attracting more and more masters of applied decorative arts with expertise and experience in the field of architectural design. In their work, we observe the harmony of national tradition and modernity.

Artist Ulugbek Boltaboev, carver Ibrahimjon Mamadaliev and woodcarver Yulbars Otaganov were invited to equip the waiting room for the Andijan airport. Each artist has fulfilled his duty to the highest level. The guests visiting our city through the airport will be in a good mood, have a beautiful feeling, and the modern building with reinforced concrete will have a national spirit. "," Playful "," swollen flower "traditional patterns, typical of the master Tiger, delight our eyes. Embroidered doors I.Mamadaliev's art of carving in a combination of attractive words, floral and geometric patterns reminiscent of Uzbek national embroidery, celestial bodies, sheets, and jewels ", - writes D. Yusupov. It is no exaggeration to say that the interior decoration of the building of the regional administration was a unique example of the use of national applied arts in its time. It is no exaggeration to say that the "Ganch Hall" of the building was an event in the history of Andijan plaster art in the work of its author I. Mamadaliev. First of all, a successful artistic solution to the art of pottery was found by a skilled craftsman. In the center of the assembly hall, there is an embossed image of the coat of arms of Uzbekistan. The wall base of the coat of arms is decorated with elegant floral and geometric patterns. The perimeter of the two sides and front walls of the stage, the perimeter of the right and back walls and the window panes on the left are also decorated with patterns that combine a unique geometric and floral pattern. Especially on the ceiling of the room, the master fully demonstrated his skill level. The composition of the patterns, the effective use of the mirror style, the success of the make-up, the elegant blue and green colors based on the patterns brought lightness, sophistication, and a special pleasant mood to 
CURRENT RESEARCH JOURNAL OF PEDAGOGICS 2(12): 90-93, December

2021 DOI: https://doi.org/10.37547/pedagogics-crjp-02-12-18

ISSN 2767-3278

(C)2021 Master Journals

Crossref dof 81 Google

Accepted $18^{\text {th }}$ December, 2021 \& Published 23 th December, 2021

the hall. The plastered doors of the "Ganch Hall" and the plastering work in the lobby of the woodcarver Y.Utaganov serve for a more beautiful and elegant interior. The symbolic mausoleum of Zahiriddin Muhammad Babur, built-in 1993 in the Bogishamol recreation area of the Bogishamol region of Andijan, the complex of museums and mosques of Babur and the world culture, was built in 2018-2019, decorated with architectural and national applied arts. will undoubtedly attract the attention of foreign and local tourists visiting dis cultural and educational centers.

The mausoleum of the scientists, designed by architect-engineer $M$. Mirzaev on the basis of national architectural traditions, has a unique appearance of a central dome and surrounding national-style porches. A creative team of wellnon artists of the region, woodcarver Yulbarsali Utaganov, carver I. Mamadaliev and majestic painter U. Boltaboev took part in the artistic decoration of the complex.

\section{REFERENCES}

1. П.Зохидов.Самарқанд меъморчиликк мактаби 19-20 аср бошлари."Фан" нашрётиТ.1965й

2. Ўзбек тилининг изохли луғати. 11-том. 414.6

3. Д.Юсупов.Эътироф китоби.54-бет.

4. Haqberdiyev, B. R., Otaxonova, S. F., \& Qodirova, D. I. (2021, November). Increasing student creativity in the integration of drawing and design sciences. In Archive of Conferences (pp. 42-43).

5. Haqberdiyev, B. R., Otaxonova, S. F., \& Qodirova, D. I. (2021). Chizmachilik va dizayn fanlarini integratsiyalash orqali takomillashtirish. Oriental renaissance: Innovative, educational, natural and social sciences, 1(10), 1189-1192.

6. Haqberdiyev, B. R. (2021). Oriental architectural monuments. the objectives and tasks of the course of designing architectural elements. ACADEMICIA: An International Multidisciplinary Research Journal, 11(7), 276-284. 